\title{
Critical government and national oil company role in their petroleum resource development: lessons for Guyana petroleum sector.
}

\author{
AZUBIKE, V.C.
}




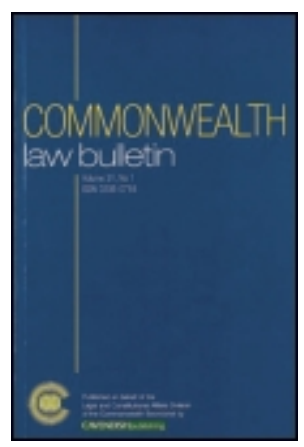

Critical Government and National Oil Company Role in Their Petroleum Resource Development: Lessons for Guyana Petroleum Sector

\begin{tabular}{|r|l|}
\hline Journal: & Commonwealth Law Bulletin \\
\hline Manuscript ID & RCLB-2020-0075.R1 \\
\hline Manuscript Type: & Articles \\
\hline Keywords: & $\begin{array}{l}\text { National Oil Company, Petroleum Resources, Governments, Guyana, } \\
\text { Economic development, Oil and Gas Law, Natural resource governance }\end{array}$ \\
\hline
\end{tabular}

\section{SCHOLARONE $^{\text {M }}$ Manuscripts}


Critical Government and National Oil Company Role in Their Petroleum Resource Development: Lessons for Guyana Petroleum Sector

\author{
Author: Victor C. Azubike \\ Robert Gordon University Aberdeen, United Kingdom \\ Email: v.c.azubike@rgu.ac.uk
}




\title{
Commonwealth Law Bulletin
}

\begin{abstract}
The discovery of vast deposits of petroleum resources in any state can arguably lead to many positive outcomes for the country, but for this favourable outcome to be actualised individual players have to perform some significant roles in achieving this goal. It has been proven that some economic development can be achieved through petroleum resources. Some studies have shown the vital roles governments, and national oil companies play in their domestic petroleum sector and even in the global petroleum sector. Recently, the national oil company model of managing petroleum resources has come under scrutiny and has been viewed as a medium of waste and corruption. This paper identifies that the national oil company model can lead to some positive outcomes for the economy of Guyana. Also, this paper identifies and analyses the critical roles a government and a national oil company play in the successful petroleum resource governance and the positive outcomes that can come from transparent and effective management of these resources. Furthermore, this paper argues the case for the presence of a national oil company in Guyana, considering that they are today considered to be a petroleum-rich state due to the sizeable recent petroleum discovery in the country.
\end{abstract}

Keywords: National Oil Companies, Petroleum resources, Guyana, Governments, International Oil Companies, Oil and Gas Law, Natural resource governance. 


\section{Introduction}

At a time that government interventions were at an all-time high in their home countries due to the Covid-19 pandemic, highlights the critical roles government play in the progress and economic development of their country. ${ }^{1}$ Also, when it comes to petroleum ${ }^{2}$ Resources, there is no doubt that the sole aim of any petroleum-rich country, whether a developed or a developing country is to maximise wealth through the exploitation of its petroleum resources. Therefore, if a country wants to achieve the national goal of fully benefitting from the exploitation of its natural (petroleum) resources, the government has a significant, strategic and facilitating role to play. Although, in the critical sense of it, fully benefitting from these resources would be difficult. However, acceptable levels where a more significant number of a population benefits from the exploration of these resources would be viewed as an adequate level, to be considered a success.

Therefore, as petroleum resources are not renewable, the need for careful management of these resources arises, and attention needs to be paid in every sphere of the value chain. Arguably, the onus is on the government to ensure this through the countries petroleum sector regulatory and legal regime. Academics such as Bentham remarked that in the global petroleum industry, petroleum development, and production takes place under many legal systems. ${ }^{3}$ Thus, regardless of the particular provisions of a legal regime petroleum exploitation usually goes on, and to consider a regulatory framework sufficient, will arguably lie on the success of the petroleum sector, the level of revenue generated from the petroleum resources and most importantly, and the economic development that is achieved through the exploitation of these resources. This, presumably, will be considered value creation through these resources.

Additionally, governments use their national oil companies (NOCs) as a tool in achieving some beneficial management and exploitation of the petroleum resources for the state. Further, the use of policies and regulations are used to attain these goals, although this is usually contingent on the objectives the governments are looking to achieve. These views to some extent are accepted by

\footnotetext{
${ }^{1}$ See 'Government Support Schemes For COVID-19' (TMF Group, 2020) <https://www.tmfgroup.com/en/news-insights/coronavirus/government-support-schemes/> accessed 1 May 2020. See also, Aimee Manning, 'COVID-19 Updates: US Federal \& State Government Relief Programs' (Linnworks, 2020) $<$ https://blog.linnworks.com/covid-19-us-government-relief-programs> accessed 1 May 2020.

${ }^{2}$ In this paper, 'petroleum' resources are used to refer to 'oil and gas' resources. Petroleum resources are predominantly defined as all liquid and gaseous hydrocarbons existing in their natural state below ground, as well as the associated substances with hydrocarbon resources. See, Bernard Taverne, Petroleum, Industry And Governments (2nd edn, Wolters Kluwer 2013) 1 - 5. See also, 'Petroleum | Energy, Products, \& Facts' (Encyclopedia Britannica, 2018) <https://www.britannica.com/science/petroleum> accessed 3 December 2018, and 'Petroleum - Schlumberger Oilfield Glossary' (Glossary.oilfield.slb.com, 2018)

$<$ http://www.glossary.oilfield.slb.com/en/Terms/p/petroleum.aspx> accessed 3 May 2018.

${ }^{3}$ R.W. Bentham, 'The International Legal Structure of Petroleum Exploration' in Judith Rees and P. R Odell (eds), The International Oil Industry (Macmillan 1987) 62-66.
} 
petroleum industry observers and analysts. ${ }^{4}$ Furthermore, as maintained by some industry analysts, NOCs have demonstrated that they can reach the levels attained by international oil companies (IOCs) and above. For instance, the creation of public revenues and acting as stewards for the petroleum resource industry and, also on the contrary if these resources are not properly managed can be a medium by which a nation's resources can be put to waste, as demonstrated by NNPC of Nigeria and Petrobras of Brazil. ${ }^{5}$ As a natural resource, petroleum resources are vital to any NOC, as this is the single resource in which most NOCs are established to deal with. Amidst the energy transition arguments from fossil fuels to renewable energy, there seems to be a consensus that petroleum still has a role to play for the foreseeable future. ${ }^{6}$

The discovery of petroleum in commercial quantities in Guyana thus calls for government leadership in achieving sustainable development. With 8 billion barrel estimate for Stabroek Block in Liza field has shot Guyana into the global petroleum market table. ${ }^{7}$ Although the ability to convert these resources to benefit the country becomes a vital task that Guyana government will have to face, to not fall into the categories of countries that experience the resource curse. According to Mangal, the government has one opportunity to get this right. ${ }^{8}$ This paper further adds that for there to be successful management of the revenue that follows, a NOC could be another option to add to Guyana's strategy to achieve

\footnotetext{
${ }^{4}$ Silvana Tordo, Brandon S Tracy and Noora Arfaa, National Oil Companies And Value Creation (World Bank 2011) xi-xiii. See also María José Paz Antolín and Juan Manuel Ramírez Cendrero, 'How Important Are National Companies For Oil And Gas Sector Performance? Lessons From The Bolivia And Brazil Case Studies' (2013) 61 Energy Policy 707 and Patrick R.P. Heller, Paasha Mahdavi and Johannes Schreuder, 'Reforming National Oil Companies: Nine Recommendations' [2014] Natural Resource Governance Institute $<$ https://resourcegovernance.org/sites/default/files/documents/nrgi_9recs_eng_v3.pdf $>$ accessed 8 November 2018.

${ }^{5}$ See Andrew C. Inkpen and Michael H Moffett, The global oil \& gas industry: Management, strategy and finance (PennWell Books 2011) 63; Patrick R P Heller, 'Doubling Down: National Oil Companies as Instruments of Risk and Reward' (2017) 81 UNU-WIDER $<$ https://www.wider.unu.edu/sites/default/files/wp2017-81.pdf $>$ accessed 14 March 2018 and David R Mares, 'Resource Nationalism and Energy Security in Latin America: Implications for Global Oil Supplies' (Scholarship.rice.edu, 2010) <https://scholarship.rice.edu/bitstream/handle/1911/91400/EF-pubMaresResourceNationalismWorkPaper-012010.pdf?sequence=1> accessed 4 March 2018.

${ }^{6}$ Tina Hunter, 'Redefining Energy Security: The New Prize in a Time of Arctic Petroleum Resources and Technological Development' in Slawomir Raszewski (ed), The International Political Economy Of Oil And Gas (Palgrave Macmillan 2018) 12-15. See also, 'The Oil And Gas Industry In Energy Transition' (IEA - World Energy Outlook Special Report, 2020) < https://www.iea.org/reports/the-oil-and-gas-industry-in-energytransitions> accessed 5 March 2020, and Anthony J. Venables, 'Using Natural Resources For Development: Why Has It Proven So Difficult?' (2016) 30 Journal of Economic Perspectives 161.

${ }^{7}$ See Dylan Baddour, 'Massive Guyana Oil Find Continues To Grow With Fresh Exxon Discovery' (Forbes, $2020)<$ https:/www.forbes.com/sites/dylanbaddour/2020/01/27/massive-guyana-oil-find-continues-to-growwith-fresh-exxon-discovery/\#5dcd47f62781> accessed 29 February 2020. See also 'Global Oil And Gas Discoveries Reach Four-Year High In 2019, Boosted By Exxonmobil's Guyana Success' (Rystad Energy, 2019) $<$ https://www.rystadenergy.com/newsevents/news/press-releases/global-oil-and-gas-discoveries-reach-fouryear-high-in-2019/> accessed 1 May 2020.

${ }^{8}$ Jan Mangal, 'Regulatory \& Risk: Securing Guyana's Future The Opportunities And The Risks' (Guyana Petroleum Summit, 2019) <https://www.guyanapetroleumsummit.com/home> accessed 30 April 2020.
} 
success through their petroleum resources. ${ }^{9}$ This paper contributes to the literature on the vital roles governments and NOCs play in the successful management of their petroleum resources.

\section{Government Roles}

As vast deposits of minerals are discovered in a country, the onus always falls on the government to come up with a strategy that will be used in the exploitation of these natural resources. Historically, during the early stage of the petroleum industry, the governments usually lack the knowledge to properly develop a coherent petroleum strategy that will enable it to gain from the exploitation of petroleum resources. For example, Norway, Denmark and the United Kingdom knew little about the oil and gas resources and its potential when petroleum resources were discovered in the North Sea. ${ }^{10}$ The same scenario can apply to a developing country that discovers large deposits of petroleum within its territory. Knowledge of petroleum resources, its economic impact and the global petroleum industry, is vital to any government in developing a sound strategy, and specific legal framework and policies in assisting the government in making sure the people benefit from the exploitation of these natural resources.

Usually, the legal framework applied to the petroleum sectors of a state sets the objectives of the government. ${ }^{11}$ These legal frameworks usually originate from the constitution, and defines the ownership of petroleum resources, followed by the legislations guiding the petroleum industry of the state. They also set out these legislation, rights, rules and procedures for granting access to the natural resources. ${ }^{12}$ Thus, establishing the administrative framework that structures the petroleum property rights, which can be in the form of concessions, licences, leases, or in any other term that is used in the state, and these can be covered in the types of contracts, or agreements and joint ventures the nation goes into with other parties, for the exploitation of their petroleum resources. ${ }^{13}$ Important to bear in mind that these petroleum resources are to be utilised for the benefit of the whole country and not for a select group.

\footnotetext{
${ }^{9}$ See Anara Khan, 'Guyana Begins Receiving Royalty From Oil On April 30' (Department of Public Information, 2020) <https://dpi.gov.gy/guyana-begins-receiving-royalty-from-oil-on-april-30/> accessed 1 May 2020.

${ }^{10}$ Svein S Andersen The Struggle Over North Sea Oil And Gas: Government Strategies In Denmark, Britain And Norway (Scandinavian University Press 1993) 2.

${ }^{11}$ Evelyn Dietsche, Sector Legal Frameworks and Resource Property Rights in Wojciech Ostrowski and Roland Dannreuther (eds), Global Resources Conflict And Cooperation (Palgrave Macmillan 2013) 159.

${ }^{12}$ Ibid., $159-162$.

${ }^{13}$ Ibid., 161. See also, John van Schaik, 'How Governments Sell Their Oil' (Resourcegovernance.org, 2012)

$<\mathrm{https} / / /$ resourcegovernance.org/sites/default/files/OilSales-HowGovtsSellOil.pdf $>$ accessed 20 February 2020.
} 
The debate of government involvement in the petroleum industry, or getting involved in the exploitation of the country's natural resources has been an ongoing one, since the entrance of governments through their NOCs in the industry. The level of government involvement in the petroleum industry varied from country to country. However, in all, there is evidence of regulations and industry policies, whether these policies changed over time or remained consistent, the importance of the government involvement was seen as vital, especially during the 1973 - 1974 oil embargo. ${ }^{14}$ Further, as the significance of the petroleum as an energy source grew, the 1973 embargo followed by the rise of oil price, it then became clear to governments especially the western European governments, that they had to be directly involved with the petroleum industry. ${ }^{15}$ Therefore, to achieve this they had two options, one was to attempt to regulate petroleum market indirectly with tariffs, taxes and licenses and the alternative was to participate directly in the petroleum industry by the establishment of national oil companies. ${ }^{16}$ Resultantly, this highlights one of the importance of a NOC in a petroleum resource-rich country and also, the importance of direct participation in the industry.

Grayson pointed out that the rise of oil price in 1979 led to the more substantial involvement of governments in the global oil and gas industry, and this was done through the establishment of NOCs. ${ }^{17}$ Though, it dawned on these governments the possible huge revenue they could gain from these resources; hence the need for control grew. Although it is yet to be seen the way governments will react to the present period of low oil prices. Regardless of what position governments take, their role remains vital in ensuring that the state benefits from the exploitation of their petroleum resources. Indeed, government influence might affect the performance of the NOCs or its ability to carry out its duties rather than attending to that, set by the present government. Additionally, as more governments started getting involved with the development of their natural resources and in the petroleum industry through their NOCs, this meant that political considerations and each country's economic well-being became the main issue, and subject in the petroleum industry. ${ }^{18}$ Private company goals of profit-making became secondary once the interest of the state became the ultimate goal. Usually, the petroleum industry was controlled and driven by IOCs. The name of the game was profiting, but as governments and NOCs started getting involved, the policies had to serve broader economic goals than the maximisation of profits. ${ }^{19}$

\footnotetext{
${ }^{14}$ Ibid., 7 - 8. See also Alan H Gelb, Oil Windfalls: Blessing Or Curse (Oxford University Press 1988) 3.

${ }^{15}$ David G Victor, David R Hults and Mark Thurber (eds) Oil and Governance (Cambridge University Press 2014) 5 .

${ }^{16}$ Ibid. See also, Bassam Fattouh, 'OPEC Pricing Power: The Need For A New Perspective' [2007] Oxford Institute for Energy Studies WPM 31.

${ }^{17}$ Leslie E Grayson, National Oil Companies (John Wiley \& Sons Ltd 1981) 1-3, 18-20.

${ }^{18}$ See Coby van der Linde, The State and The International Oil Market (Kluwer Academic Publishers 2000) 9.

${ }^{19}$ Ibid.
} 
Traditionally, governments are expected to regulate the state's petroleum industry, to be able to create value for the public from the exploitation of petroleum resources. ${ }^{20}$ This means that the governments are expected to formulate the policies for all the phase of the state's petroleum industry. Fundamentally, each government is expected to develop and follow a petroleum policy that targets the promotion of the state's interest in petroleum affairs within and outside of its territory, as the ultimate goal would be creating value for the people through these petroleum resources. ${ }^{21}$

Additionally, the International Energy Agency (IEA) captured the importance of government, policy and regulatory frameworks in the following statement:

for it is governments that "hold the key to changing the mix of energy investment" and it is the policy and regulatory frameworks that they establish, nationally and internationally... ${ }^{22}$

The IEA statement supports the argument that the government has a huge role to play in the creation of value and benefits through the petroleum resources of the state. As the drilling of the first oil well marked the beginning of the petroleum industry, correspondingly this also prompted the start of the development of mining legislation that would guide the petroleum industry and its operations. ${ }^{23}$ Petroleum legislation consists of all laws, regulations, rules and policies that are designed to regulate the state's petroleum industry and its operations. ${ }^{24}$ Important to note, that the petroleum industry changes from time to time as has been evidenced from its history, therefore it is usually expected that these petroleum frameworks evolve with the industry, as to maintain the state's ability to create value through the petroleum resources. Although this is generally viewed upon the level of revenue, the state accrues from exportation of the petroleum resources.

Furthermore, through policies, laws and regulations, governments directly intervene in the petroleum industry and directly through its participation and investment in the petroleum industry. ${ }^{25}$ According to Sarbu, differing from the contested main sectoral objective of commercial activities that will increase the revenue of the state for any petroleum resource-rich developing country, one might argue that this

\footnotetext{
${ }^{20}$ Thomas W Wälde, 'International Energy Law: Concepts, Context And Players: A Preliminary Introduction' (2003) 1 OGEL.

${ }^{21}$ See Bernard Taverne, An Introduction To The Regulation Of The Petroleum Industry (Graham \& Trotman 1994) $97-80$.

${ }^{22}$ Neil Gunningham, 'Regulation, Economic Instruments and Sustainable Energy' in Andreas Goldthau The Handbook of Global Energy Policy (John Wiley \& Sons Inc 2013) 305. See also, Ralf Boscheck, 'The Governance Of Oil Supply: An Institutional Perspective On NOC Control And The Questions It Poses' (2007) 1 International Journal of Energy Sector Management 366.

${ }^{23}$ See Thomas Walde, 'Investment Policies in the International Petroleum Industry: responses to the Current Crisis' in Khan (ed), Petroleum Resources And Development (Belhaven 1988) 32.

${ }^{24}$ Bernard Taverne (n 19) 115.

${ }^{25}$ See Øystein Noreng, 'Global Resource Scramble and New Energy Frontiers' in Andreas Goldthau (n 21) 171. See also Dr. S.K. Date-Bah and Makbul Rahim, Promoting Petroleum Exploration and Development: Issues for Government action in Khan (ed) (n 24) $106-109$.
} 
is not usually obtainable. ${ }^{26}$ Instead, the seeking of rent and ways to increase the rents that can be received from the exploitation of its natural resources is what drives the government and its policies. ${ }^{27}$ The capability for a government to gain huge rents from the petroleum resources is equally commendable. However, commercial activities by the state's NOC could be a sustainable measure. As they are mandated by the state to ensure steady revenue stream for the country. Therefore, in a case the state's petroleum resources dry up one day, then the NOC's commercial expertise can help the government continue the generation of the revenue through its international petroleum activities.

Additionally, today the importance of governments in the petroleum industry cannot be ignored because the development of international petroleum strategies strongly requires the input of governments, whether from petroleum exporting or importing countries. ${ }^{28}$ The government of any petroleum-rich state is usually expected to be able to manage these resources in the interest of the country. However, there is a view that governments are often at a disadvantage when entering into a contract with IOCs or any mineral company, as these companies are more knowledgeable in the industry than the government. ${ }^{29}$ For example, the recent reports on Exxon-Mobil and Guyana contracts, where allegations were levelled against the IOCs for cheating the Guyanese government and state over 55 Billion Dollars over the agreement they entered into with the company. ${ }^{30}$ Whatever the case may be in Guyana, the burden is on the government to ensure that the people get a fair share and benefit from these petroleum resources discovered within its territory. Closer attention should be paid in the agreements the country goes into, and also the petroleum industry is very different from what it used to be a couple of years back.

Further, the government playing the role of the sovereign owner on behalf of the people, according to Sarbu, is one government role that has been contested. However, the energy policies are set by the government and the part of the NOC also, it can be argued that the government is a steward and not the owner of the natural resources since the natural resource is for the people. ${ }^{31}$ Also, relationships between governments, NOCs and IOCs are usually guided by upstream legal frameworks and fiscal regimes. Although, these legal frameworks and fiscal regimes can also, regulate the midstream and downstream

\footnotetext{
${ }^{26}$ Bianca Sarbu Ownership and Control of Oil: Explaining Policy Choices Across Producing Countries (Routledge 2014) 26 - 27.

${ }^{27}$ Ibid.

${ }^{28}$ See Andrew Bauer and Juan Carlos Quiroz, 'Resource Governance' in Andreas Goldthau (n 21) 245 - 246.

${ }^{29}$ John Mitchell, Valerie Marcel and Beth Mitchell, 'What Next For The Oil And Gas Industry' (Chatham House, 2012)

$<$ https://www.chathamhouse.org/sites/files/chathamhouse/public/Research/Energy,\%20Environment\%20and\%2 0Development/1012pr oilgas.pdf $>$ accessed 10 February 2018.

${ }^{30}$ See Jonathan Gant, 'Signed Away: How Exxon's Exploitative Deal Deprived Guyana Of Up To US\$55

Billion | Global Witness' (Global Witness, 2020) < https://www.globalwitness.org/en-gb/campaigns/oil-gas-andmining/signed-away-exxons-exploitative-deal-deprived-guyana/> accessed 9 February 2020.

${ }^{31}$ Bianca Sarbu (n 25) $26-27$.
} 


\footnotetext{
32 Honoré Le Leuch, 'Recent Trends in Upstream Petroleum Agreements: Policy, Contractual, fiscal, and Legal Issues' in Andreas Goldthau (n 21) 127.

${ }^{33}$ Ibid. (n 23) 130.

${ }^{34}$ Honoré Le Leuch in Andreas Goldthau (n 21) 130.

${ }^{35}$ Ibid.

${ }^{36}$ Ibid.

${ }^{37}$ Bianca Sarbu (n 25) 26-27.

${ }^{38}$ Ibid.
} 
Accordingly, the state promulgates an upstream petroleum law which defines the whole upstream sector process, from types of agreements ${ }^{39}$ Terms and conditions to be met, exploration, exploitation operations and the applicable petroleum tax regime. ${ }^{40}$ It is important to note that overtime countries might decide to review or change their policies, especially fiscal policies. Introduction of new terms in upstream petroleum contracts and tax systems always evolve, and this can be arguably tied to the political evolution of the country, whether the country is developed or developing, these changes occur. ${ }^{41}$ Hopefully, this change of the country's petroleum framework will have value creation for the people of the state at heart, thereby ensuring that the people continue to benefit from the petroleum resources.

Furthermore, arguments of leaving petroleum resources in the hands of the market or private sector, or have the government usually intervene by the NOCs which is conventionally the government agent has been going on for a while. For all the argument against the government intervention in the exploitation of a developing countries' petroleum resources it is essential to note that the developed or industrialised countries have a 'self-sustained' economy whereas the developing countries did not. ${ }^{42}$ So the discovery of petroleum resources in these developed countries was made within a well-defined or somewhat wellstructured economy, unlike when petroleum is discovered in a developing country with the less structured economy. This scenario is somewhat applicable to the case of Guyana.

These petroleum resources are expected to be managed with the interest of the public at the forefront, and not the benefit of a select group of elites. According to Van de Linde, the expected government roles as a maximiser of social welfare both as an economic regulator and a provider of public goods is what the 'public interest' theories highlights. ${ }^{43}$ Although, much criticism has been level on this theory, mainly that the present government will use this to further its political interests which seldom aligns with social welfare and therefore create misguided policies. ${ }^{44}$ One can say this situation makes it pertinent for the government intervention to properly regulate the petroleum industry rather than leave

\footnotetext{
39. The following are the three main types of agreements used in the petroleum industry: Concession Agreement, Production Sharing Contract (PSC) and Risk Service Contract (RSC) See Honoré Le Leuch, 'Recent Trends in Upstream Petroleum Agreements: Policy, Contractual, fiscal, and Legal Issues' in Andreas Goldthau (n 21) 132 -134 .

${ }^{40}$ Honoré Le Leuch in Andreas Goldthau (n 21) 129.

${ }^{41}$ Ibid.

42 Coby van der Linde (n 17) 27-35.

${ }^{43}$ Ibid. See also, Richard A. Posner, 'Theories Of Economic Regulation' (1974) 5 Bell Journal of Economic 335; Gilbert Becker, 'The Public Interest Hypothesis Revisited: A New Test Of Peltzman's Theory Of Regulation' (1986) 49 Public Choice 223; Theodore E. Keeler, 'Theories Of Regulation And The Deregulation Movement' (1984) 44 Public Choice 103, and Michael Hantke-Domas, 'The Public Interest Theory Of Regulation: NonExistence Or Misinterpretation?' (2003) 15 European Journal of Law and Economics 165.

${ }^{44}$ Ibid. See also, Andrei Shleifer, 'Understanding Regulation' (2005) 11 European Financial Management 439, and Oliver James, 'Regulation Inside Government: Public Interest Justifications And Regulatory Failures' (2000) 78 Public Administration 327.
} 
it to the world market forces. As a state's petroleum sector is affected by domestic and international factors.

Furthermore, control has always been an essential factor in the petroleum industry, from the direct control over the revenues from the exploitation of petroleum resources to the control of how the income from these resources is redistributed. This was and is still the concern of these petroleum-producing state's governments. ${ }^{45}$ For example, according to Andersen, control of its petroleum industry has always been the goal of the Norwegian government, securing the lion share of the possible income from the exploitation of its resources was the long-term goal, and this was achieved through the control over the day-to-day activities of the industry. ${ }^{46}$ It can be drawn that the intentions and objectives of the governments towards the management of its petroleum resources can be gleaned from the legislation enacted that is targeted towards this goal.

Finally, in elaborating the role of government in petroleum development Van de Linde observed that it is a well-known fact that the government's role is usually one of law and order; therefore the arguments has been one of making sense of law and order in an economic dimension, from the NOCs involvement in production, while also having the government regulate the industry, thereby having an effect on the private economy. ${ }^{47}$ Therefore, this gives a petroleum industry a structure when the government's framework is one that seeks to create value for the people from the petroleum resource of the state.

\section{National Oil Companies Role}

Notably, since 1991 nearly $90 \%$ of the conventional crude oil reserves have been controlled by NOCs, however, this control over the petroleum resources over this period has not led to operational efficiency as the works of Eller and others, suggested. ${ }^{48}$ Furthermore, as indicated by Eller and the foregoing authors. this inefficiency stems mainly from how profits are redistributed and the high degree of political influence over these NOCs granted that most NOCs are used as political tools by their governments. One might argue that with the right policies and legal framework that directs and guides the objectives of the NOCs, they can efficiently perform as well as the IOCs.

\footnotetext{
${ }^{45}$ Coby van der Linde (n 17) 27-35.

${ }^{46}$ Svein S Andersen ( n 10) 63.

${ }^{47}$ Coby van der Linde (n 17) $27-35$.

${ }^{48}$ Stacy L. Eller, Peter R. Hartley and Kenneth B. Medlock, 'Empirical Evidence on the Operational Efficiency of National Oil Companies' (2010) 40 Empirical Economics. See also, Chidi Basil Ike and Hyunjung Lee, 'Measurement Of The Efficiency And Productivity Of National Oil Companies And Its Determinants' (2014) 17 Geosystem Engineering; Peter Hartley and Kenneth B. Medlock, 'A Model Of The Operation And Development Of A National Oil Company' (2008) 30 Energy Economics 2460; Paul Markwell and others, 'The New Frontier For National Oil Companies' [2014] SSRN Electronic Journal.
} 
Yergin et al. pointed out that the birth of the NOCs generally described being the event that took place in 1908 Austria-Hungary when Emperor Franz Joseph's approval of the building of a topping plant. During that period private oil producers encountered surplus supply of crude, and this topping plant was owned and operated by the government. ${ }^{49} \mathrm{McPherson}$ pointed out that as the need to secure energy supplies grew in the minds of the Western governments, the need to establish a government entity that would achieve the security and diversity of energy supply while going into contracts with IOCs on behalf of the state also grew. ${ }^{50}$ What followed in the coming years was the establishment of NOCs by various governments around the world.

Petroleum has been argued to be a political commodity, and the international domain in which petroleum resources are produced and traded is mainly political. Why one may ask? It is debatable that the push to secure access to petroleum resources has always been fundamental to geopolitics and international relations. For instance, energy security has driven international politics, from European imperial expansion and industrialisation of the $19^{\text {th }}$ century and the scramble for raw materials in Africa. ${ }^{51}$

Furthermore, often in a developing petroleum-rich state, the NOCs are unceremoniously controlled by the ruling party and elite group. ${ }^{52}$ The politicised NOC board and executive management, coupled with the controlling elite group who show little or no interest in the overall performance of the NOC, instead they seek to use the NOC to achieve the group's goals rather than the states. ${ }^{53}$ This undermining of the corporate governance structure of the NOC affects the organisational performance of the NOC and disrupts the transparency process, which leads to corruption and mismanagement of funds. As with the other negative examples, NNPC in Nigeria provides a classic example of these governance and transparency problems. A critical step or process in improving the governance in the petroleum sector of a state has been observed to be transparency. ${ }^{54}$ Powerfully essential to know whether these NOCs were set up by an act of parliament (legislation) or they were incorporated as a company through the

\footnotetext{
${ }^{49}$ In 1914 the government of the United Kingdom purchased 51\% ownership share in Anglo-Persian Oil Company (which later became British Petroleum). See Daniel Yergin, The Prize (Simon \& Schuster 2012) 130 and Andrew C. Inkpen and Michael H Moffett (n 5) $52-55$.

${ }^{50}$ Charles Mcpherson and World Bank Group, 'National Oil Companies Evolution, Issues, Outlook National Oil Companies Workshop Current Roles and Future Prospects' (World Bank Washington D.C. 2003)

${ }^{51}$ See Roland Dannreuther, Geopolitics and International Relations of Resources in Wojciech Ostrowski and Roland Dannreuther (eds.), Global Resources Conflict And Cooperation (Palgrave Macmillan 2013) 79-81 and Caroline Kuzemko, Andrew Lawrence and Matthew Watson, 'New Directions In The International Political Economy Of Energy' (2019) 26 Review of International Political Economy 1.

${ }^{52}$ Lindsay Whitfield and Lars Buur, 'The Politics Of Industrial Policy: Ruling Elites And Their Alliances' (2014) 35 Third World Quarterly 126.

${ }^{53}$ See Charles Mcpherson in Andreas Goldthau (n 21) $151-152$.

${ }^{54}$ Ibid.
} 
filing and registration at the company house. ${ }^{55}$ Important to know a NOC's legal status can show an agent of the government, whether it was constituted by an act of parliament or incorporated through the company act. ${ }^{56}$

Additionally, NOC failure can have terrible consequences for the country, as has been witnessed in some petroleum-rich states. ${ }^{57}$ It is known that the overall objectives of every states petroleum sector are defined at the very top of government and depending on the political system in the state when it comes to a decision making in relations to the petroleum or petroleum resources of the country, it might be subject to public debate and parliamentary approval. ${ }^{58}$ However, in reality, NOCs should be concerned with the overall economics and industrial matters rather than the political side of the industry. ${ }^{59}$ Although this might be true in some countries, it is clear that NOCs are always affected and influenced by politics, especially the NOCs from a developing state. This is so because the government is the one that develops the petroleum policies, and legal framework that guides the NOCs and appoints the board of directors, and in many cases subsidise the operations of the NOCs. ${ }^{60}$

In today's global petroleum industry, the definition of a National Oil Company cannot be restricted to one. Further, in an attempt to define the term national oil companies while noting the ambiguity in the term, Grayson stated that when a company is being used for a public purpose, it can be said to be a national oil company. ${ }^{61}$ Although, this social purpose has to be connected to the management of the states petroleum resources, as states do have different government entities that manage various resources and sectors. Furthermore, Paul Stevens defined a NOC as 'an oil and gas company operating in some part of the oil and gas value chain owned and controlled by the government'. ${ }^{2}$ In other words, NOCs were created to ensure state control over any country's petroleum resources and to ensure higher revenues from petroleum production. ${ }^{63}$ High revenue and achieving economic development through the effective management of petroleum resources became the primary purpose of establishing a NOC.

\footnotetext{
${ }^{55}$ Eze Emem Chioma, 'How Has The Ability Of The NNPC To Make A Profit Been Hampered By The Retention Of Its Corporate Status As A Statutory Body Rather Than As A Separate Legal Entity Under The NNPC Act 1977?' (2015) 8 International Energy Law Review 304.

${ }^{56}$ V. K. Moorthy, 'The Malaysian National Oil Corporation — Is It A Government Instrumentality?' (1981) 30 International and Comparative Law Quarterly 638 and Eze Emem Chioma n 54.

57 Oystein Noreng n 24.

${ }^{58}$ Additionally, the type of NOC also defines the decision-making area of responsibility of the government in the states oil and gas industry. See Bianca Sarbu (n 25) 24.

59 Valérie Marcel and John V Mitchell, Oil Titans: National Oil Companies In The Middle East (Chatham House 2006) 3 - 4. See also, Dag Harald Claes, The Politics Of Oil-Producer Cooperation (Routledge 2018$) 2$.

${ }^{60}$ Valérie Marcel and John V Mitchell (n 58) 4.

${ }^{61}$ Leslie E Grayson (n 16) 5.

62 Paul Stevens, 'National Oil Companies: Good Or Bad' (2003) $<$ https://pdfs.semanticscholar.org/49e9/e0b16dd0bb57fbb6c996ec0f5c5cfb2babbd.pdf $>$ accessed 4 February 2018.

${ }^{63}$ See 'National Oil Companies (NOCs)' (Extractives Hub, 2020)

$<$ https://extractiveshub.org/servefile/getFile/id/4220> accessed 27 February 2020.
} 
Although the ability of these NOCs to achieve these goals is another debate altogether. The above arguments apply to any petroleum-rich state, such as Guyana, that is looking forward to demonstrate control over their petroleum resources.

NOCs controlling petroleum reserves can be beneficial to a state, as far as the control results in efficient redistribution of the petroleum resource revenue that benefits the people of the country. It is debatable to say that political objectives will overtake the petroleum industry if the NOCs continue to assert their control over it, is very much debatable. ${ }^{64}$ If one follows the history of the global petroleum industry, even when it was controlled by the IOCS (seven sisters), one can see that politics and petroleum resources go hand in hand. Hence, that is why petroleum resources are usually referred to as political commodities.

Rather than discouraging the continuation of the state control and ownership over their petroleum industry, the direction should be to encourage these states, and their NOCs to adopt efficient methods through strong petroleum industry policies and legal frameworks. ${ }^{65}$ When a government is endowed with petroleum resources, it is usually assumed that the way its resources are regulated, or the regulatory framework guiding its petroleum industry, will show the objectives and aims of the government, and what it seeks to achieve. For example, this can be observed in the tax policies adopted by Russia points to a broader economic and geostrategic rationale, which shows the government's desire to use the control of its petroleum resources to build its economy and at the same time reassert its authority on the global petroleum industry. ${ }^{66}$ However, this strategy has been argued as a means used by the Russian government in destroying Yukos.

Furthermore, it is vital for a country that is blessed with an abundance of petroleum resources to perfect their legislation that concerns these natural resources, also improving the economic mechanisms for the resource exploitation and, defining and also rectifying the system of licensing and regulations in the area of the exploitation of its petroleum resources. ${ }^{67}$ It is also important to mention that within the petroleum-producing countries, their various NOCs differ from each other. While in some of these countries the NOCs participate with other companies or IOCs in a licensing regime others exercise complete state ownership and control in exploitation. ${ }^{68}$

\footnotetext{
${ }^{64}$ See Stacy L. Eller, Peter R. Hartley and Kenneth B. Medlock, 'Empirical Evidence on the Operational Efficiency of National Oil Companies' (2010) 40 Empirical Economics.

${ }^{65}$ Harley Balzer, 'The Putin Thesis And Russian Energy Policy' (2005) 21 Post-Soviet Affairs 210.

${ }^{66}$ Ibid.

${ }^{67}$ Ibid.

${ }^{68}$ Coby van der Linde (n 17) 12-13.
} 
${ }^{69}$ See The National Oil Company Database: Report (National Oil Company Database, 2019)

$<$ https://www.nationaloilcompanydata.org/api/publications/content/NFInSnhdYNC4ntCohaYqok1u2jHAG4vvL XK1jwrL.pdf $>$ accessed 25 June 2019.

70 See Dylan Baddour, 'Massive Guyana Oil Find Continues To Grow With Fresh Exxon Discovery' (Forbes, $2020)<\mathrm{https}$ //www.forbes.com/sites/dylanbaddour/2020/01/27/massive-guyana-oil-find-continues-to-growwith-fresh-exxon-discovery/\#5dcd47f62781> accessed 29 February 2020. See also, Clifford Krauss, 'With A Major Oil Discovery, Guyana Is Poised To Become A Top Producer' (The New York Times, 2017) $<$ https://www.nytimes.com/2017/01/13/business/energy-environment/major-oil-find-guyana-exxon-mobilehess.html> accessed 1 May 2020.

${ }^{71}$ David Mihalyi and Andrew Bauer, 'Challenges And Opportunities In Managing Guyana's Oil Wealth' (2020) 18 OGEL. See also 'Guyana's Dodgy Poll Is All About Oil' (The Economist, 2020) $<$ https://www.economist.com/leaders/2020/03/19/guyanas-dodgy-poll-is-all-about-oil > accessed 23 March 2020 .

${ }^{72}$ Kevin Ramnarine, 'Considerations For A Regulatory Framework To Granting E\&P Rights A Regional Perspective' (Guyana Petroleum Summit, 2019)

$<$ https://www.guyanapetroleumsummit.com/page/1421919/presentations> accessed 30 April 2020.

${ }^{73}$ See 'Guyana: Country Review' (CountryWatch, 2019)

$<$ http://www.countrywatch.com/intelligence/countryreviews?countryid=72> accessed 30 April 2020. See also Eric N. Smith, 'A Status Report On Economic And Political Conditions In Guyana, A World Class Hydrocarbon Discovery' (2020) 18 OGEL. 


\footnotetext{
${ }^{74}$ See Ramez Abubakr Badeeb, Hooi Hooi Lean and Jeremy Clark, 'The Evolution Of The Natural Resource Curse Thesis: A Critical Literature Survey' (2017) 51 Resources Policy 123. See also Robert Deacon, 'The Political Economy Of The Natural Resources Curse: A Survey Of Theory And Evidence' (2011) 7 Foundations and Trends ${ }^{\circledR}$ in Microeconomics 111; Jeffrey A. Frankel, 'The Natural Resource Curse: A Survey' [2010] National Bureau of Economic Research Working Paper No. 15836; Anthony J. Venables n 2; Frederick van der Ploeg, 'Natural Resources: Curse Or Blessing?' (2011) 49 Journal of Economic Literature 366 and Hajime Takatsuka, Dao-Zhi Zeng and Laixun Zhao, 'Resource-Based Cities And The Dutch Disease' (2015) 40 Resource and Energy Economics 57.

75 See Daron Acemoglu, Simon H. Johnson and James A. Robinson, 'An African Success Story: Botswana' (2001) Working Paper 01-37 SSRN Electronic Journal 1. See also, Peter Cameron and Michael Stanley, The Extractive Industries Sourcebook (World Bank Group 2017) 4-6, and Maria Sarraf and Moortaza Jiwanji, 'Beating The Resource Curse: The Case Of Botswana' (The World Bank, 2001) $<$ https://openknowledge.worldbank.org/bitstream/handle/10986/18304/multi0page.pdf?sequence=1 $>$ accessed 7 March 2019. See also Anthony J. Venables, 'Using Natural Resources For Development: Why Has It Proven So Difficult?' (2016) 30 Journal of Economic Perspectives 161.

${ }^{76}$ David Mihalyi and Andrew Bauer, 'Challenges And Opportunities In Managing Guyana's Oil Wealth' (2020) 18 OGEL.

77 See Morgan D. Bazilian and Paasha Mahdavi, 'New Oil Finds Could Mean A Tripling Of Guyana's GDP' (Foreign Policy, 2020) <https://foreignpolicy.com/2019/11/26/new-oil-finds-triple-guyana-gdp-avoid-resourcecurse/> accessed 1 March 2020. See also, Christopher M. Matthews and Kejal Vyas, 'World's Biggest New Oil Find Turns Guyana Upside Down' (The Wall Street Journal, 2020) < https://www.wsj.com/articles/worldsbiggest-new-oil-find-turns-guyana-upside-down11582909332? redirect=amp\#click=https://t.co/PBMgPbuRXS $>$ accessed 29 February 2020.

${ }^{78}$ See Ian Bremmer, 'The End Of The Free Market: Who Wins The War Between States And Corporations?' (2010) 24 Ethics \& International Affairs 249 - 252.
} 


\footnotetext{
${ }^{79}$ Serik Orazgaliyev, 'State Ownership And Nationalization In Energy Sector: The Case Of Kazakhstan's Oil Industry' [2019] Asian Development Bank Institute Working Paper No. 1042.

${ }^{80}$ See 'Who's Who In The Oil And Gas Sector In Guyana' (OilNow, 2020)

$<$ https://oilnow.gy/profiles/companies/whos-who-in-the-oil-and-gas-sector-in-guyana/> accessed 30 April 2020.

${ }^{81}$ Alicia Elias-Roberts, 'A Review Of The Legal Framework Of Local Content Provisions In Guyana' (2020) 18 OGEL.

${ }^{82}$ Charles Ramson Jr., 'Guyana Missed Golden Opportunities To Have National Oil Company With Interest In Offshore Blocks' (Kaieteur News, 2019) <https://www.kaieteurnewsonline.com/2019/04/12/guyana-missedgolden-opportunities-to-have-national-oil-company-with-interest-in-offshore-blocks-ramson-jr/> accessed 30 April 2020.

${ }^{83}$ Ibid., See 'Guyana To Establish National Oil Company Soon - Guyana Chronicle' (Guyana Chronicle, 2018) $<$ http://guyanachronicle.com/2018/05/20/guyana-to-establish-national-oil-company-soon> accessed 30 April 2020 .
} 
should help the country to control its resources appropriately, and it brings with it the international and domestic political advantage. ${ }^{84}$

Another reason for a NOC creation is the benefits of state control, through direct involvement in the activity of the petroleum industry by its NOC which can solve the broader socio-economic issues. ${ }^{85}$ Another view is that the establishment of NOCs enable the petroleum-producing states to nationalise their resources, as it gave them the technical and organisational competence to take control of the operations of the IOCs. ${ }^{86}$ Similarly, Victor and others. also remarked that the fact drove governments when establishing NOCs, that state ownership of the petroleum resources will assist the government to effectively promote and control economic development, redistribute the income gotten from the petroleum resources, and help national pride. ${ }^{87}$ How well this worked out for the majority of the governments that setup NOCs for this purpose is yet to be evidenced, but as evidenced in some success stories mentioned earlier in this paper proves that for Guyana it should be a plan to consider. Further, the type of NOC Guyana decides to establish will be determined by many factors as NOCs usually vary in form or organisational structure: from differences in size, geographical endowment, experience, mandate, goals set by the NOC as a company and also goals prioritised by their various governments. ${ }^{88}$

Finally, for all the commentary that the NOC model is not the best option for a petroleum-rich state, this paper argues against that. Also, the history of the global petroleum industry proves otherwise. The argument that the days of NOCs as tools of government control of petroleum resources are numbered is one of this paper's debates. Further, this paper claims that NOCs are still relevant as they were years ago, and they have the potential to be the critical government entity that could assist Guyana primarily to reap the benefits of its petroleum resources. As at present petroleum industry experts are concerned that amid all the political turmoil in Guyana it seems the state is not ready for the vast stream of revenue coming from the petroleum resources. ${ }^{89}$ Further buttresses the point of this paper, because as these avalanche of petrodollars are received by the state, it should be in a perfect and stable form to properly

\footnotetext{
${ }^{84}$ See Bianca Sarbu (n 25) 36.

${ }^{85}$ Ibid.

${ }^{86}$ Valérie Marcel and John V Mitchell (n 58) 29 -30.

${ }^{87}$ David G Victor, David R Hults and Mark Thurber (eds) (n 15) 8 - 9. See also, Ole Gunnar Austvik, 'Landlord And Entrepreneur: The Shifting Roles Of The State In Norwegian Oil And Gas Policy' (2011) 25 Governance 315, and Paul Stevens n 43.

${ }^{88}$ See Patrick Heller, 'National Oil Company Database: Global Launch' (National Resources Governance Institute, 2019)

$<$ https://www.nationaloilcompanydata.org/api/publications/content/MvBx7qBCgtu0iILVzQGU2yhswUiFrmxx dwNuaT9C.pdf $>$ accessed 25 June 2019. See also, Saud M. Al-Fattah, 'National oil companies: Business models, challenges, and emerging trends' (2013) 11(1) SSRN Electronic Journal 727-736.

${ }^{89}$ See Steve LeVine, 'The Surprising Next Oil Superpower' (AXIOS, 2019) <https://www.axios.com/guyanacould-become-the-next-wealthy-oil-nation-b7d7c831-10ae-4a40-bfe5-cb4e9c58d10f.html > accessed 6 May 2020. See also, Anatoly Kurmanaev, 'Crisis Deepens In Tiny Guyana, The World'S Newest Petro State' (The New York Times, 2020) <https://www.nytimes.com/2020/03/06/world/americas/Guyana-election.html $>$ accessed 10 March 2020.
} 
manage these windfalls. Unless these resources could lead to the nation falling into the category of countries affected by the resource curse.

\section{Conclusion}

The above analysis goes to show that government always have a strong role to play in the exploitation of natural resources. Although some might relinquish their position to the private sector later on, for the formative years of the petroleum industry in most countries, the government has a dominant role to play. Importantly, NOC as the tool for achieving the goals of the state towards the beneficial exploitation of its resources is indispensable. NOCs activities influence domestic development through its impact on macroeconomic management, investment and overall governance and stability, and in like manner how well a NOC performs not only affect its local economy, it also has significant ramification on the international energy supply and security. ${ }^{90}$

The analysis of this paper draws the theme of the argument of maintaining a NOC. The analysis also goes to show the need for an entity that can be used to exert control over the petroleum resources. For a developing country like Guyana, the importance of a NOC as a tool of the government to exercise its authority over its resources is vital. Mommer remarked that today, NOCs can be transformed into new liberal licensing, and contracting agencies, which was contrary to their duties in the past where they were used as rent collecting agents of the state or 'landlord state' as Mommer calls them. ${ }^{91}$ However, nationalisation expanded the role of NOCs tremendously. ${ }^{92}$ Although, today one can say, that some of these NOCs in petroleum-rich states, especially the developing ones, still limit their NOCs to petroleum-rent collectors. Evidently, when NOCs are well managed and guided by the legal framework and petroleum policies can be highly beneficial to the people of Guyana. As a result, delivering substantial value to shareholders through the fiscal revenue contributions to the treasury of a state, successful exploration efforts, and the development of new skills and technologies is usually a mark of effective NOCs..$^{93}$

\footnotetext{
${ }^{90}$ Charles Mcpherson in Andreas Goldthau (n 21) 146. See Leonardo Maugeri, 'Oil: The Next Revolution' [2012] The Geopolitics of Energy Project < http://indianstrategicknowledgeonline.com/web/Oil\%20The\%20Next\%20Revolution.pdf $>$ accessed 8 November 2018.

${ }^{91}$ Bernard Mommer, Global Oil And The Nation State (Oxford University Press 2002) 183.

92 Ibid.

${ }^{93}$ See The National Oil Company Database: Report (National Oil Company Database, 2019) $<$ https://www.nationaloilcompanydata.org/api/publications/content/NFInSnhdYNC4ntCohaYqok1u2jHAG4vvL XK1jwrL.pdf $>$ accessed 25 June 2019.
} 


\section{References}

- Acemoglu D, Johnson S. H, and Robinson J. A, 'An African Success Story: Botswana' (2001) Working Paper 01-37 SSRN Electronic Journal

- Andersen S, The Struggle Over North Sea Oil And Gas: Government Strategies In Denmark, Britain And Norway (Scandinavian University Press 1993)

- Antolín M. J. P, and Cendrero J.M.R, 'How Important Are National Companies For Oil And Gas Sector Performance? Lessons From The Bolivia And Brazil Case Studies' (2013) 61 Energy Policy

- Austvik O, 'Landlord And Entrepreneur: The Shifting Roles Of The State In Norwegian Oil And Gas Policy' (2011) 25 Governance

- Badeeb R. A, Lean H. H, and Clark J, 'The Evolution Of The Natural Resource Curse Thesis: A Critical Literature Survey' (2017) 51 Resources Policy

- Baddour D, 'Massive Guyana Oil Find Continues To Grow With Fresh Exxon Discovery' (Forbes, 2020) <https:/www.forbes.com/sites/dylanbaddour/2020/01/27/massive-guyana-oilfind-continues-to-grow-with-fresh-exxon-discovery/\#5dcd47f62781> accessed 29 February 2020

- Balzer H, 'The Putin Thesis And Russian Energy Policy' (2005) 21 Post-Soviet Affairs

- Basil C. I, and Lee H, 'Measurement Of The Efficiency And Productivity Of National Oil Companies And Its Determinants' (2014) 17 Geosystem Engineering

- Barnes L, 'Spotlight On Guyana's Impending Oil Wealth' (Petroleum Economist, 2020) $<$ https://www.petroleum-economist.com/articles/politics-economics/south-centralamerica/2020/spotlight-on-guyana-s-impending-oil-wealth> accessed 29 February 2020

- Bazilian M, and Mahdavi P, 'New Oil Finds Could Mean A Tripling Of Guyana's GDP' (Foreign Policy, 2020) <https://foreignpolicy.com/2019/11/26/new-oil-finds-triple-guyanagdp-avoid-resource-curse/> accessed 1 March 2020

- Becker G, 'The Public Interest Hypothesis Revisited: A New Test Of Peltzman's Theory Of Regulation' (1986) 49 Public Choice 
- Bentham R. W, 'The International Legal Structure of Petroleum Exploration' in Judith Rees and P. R Odell (eds), The International Oil Industry (Macmillan 1987)

- Boscheck R, 'The Governance Of Oil Supply: An Institutional Perspective On NOC Control And The Questions It Poses' (2007) 1 International Journal of Energy Sector Management

- Bremmer I, 'The End Of The Free Market: Who Wins The War Between States And Corporations?' (2010) 24 Ethics \& International Affairs

- Cameron P and Stanley M, The Extractive Industries Sourcebook (World Bank Group 2017)

- Chioma E, 'How Has The Ability Of The NNPC To Make A Profit Been Hampered By The Retention Of Its Corporate Status As A Statutory Body Rather Than As A Separate Legal Entity Under The NNPC Act 1977?' (2015) 8 International Energy Law Review

- Claes D, The Politics Of Oil-Producer Cooperation (Routledge 2018)

- Crowley K, 'Guyana Slams Activist Group's "Cunning And Calculated Attack" On Exxon Deal' (World Oil, 2020) <https://www.worldoil.com/news/2020/2/5/guyana-slams-activistgroup-s-cunning-and-calculated-attack-on-exxon-deal $>$ accessed 29 February 2020

- Deacon R, 'The Political Economy Of The Natural Resources Curse: A Survey Of Theory And Evidence' (2011) 7 Foundations and Trends ${ }^{\circledR}$ in Microeconomics

- Elias-Roberts A, 'A Review Of The Legal Framework Of Local Content Provisions In Guyana' (2020) 18 OGEL

- Eller S, Hartley P, and Medlock K, 'Empirical Evidence On The Operational Efficiency Of National Oil Companies' (2010) 40 Empirical Economics

- Fattouh B, 'OPEC Pricing Power: The Need For A New Perspective' [2007] Oxford Institue for Energy Studies WPM 31

- Frankel J. A, 'The Natural Resource Curse: A Survey' [2010] National Bureau of Economic Research Working Paper No. 15836

- Gant J, 'Signed Away: How Exxon's Exploitative Deal Deprived Guyana Of Up To US\$55 Billion' (Global Witness, 2020) <https://www.globalwitness.org/en-gb/campaigns/oil-gas-andmining/signed-away-exxons-exploitative-deal-deprived-guyana/> accessed 29 February 2020 
- 'Global Oil And Gas Discoveries Reach Four-Year High In 2019, Boosted By Exxonmobil'S Guyana Success' (Rystad Energy, 2019) $<$ https://www.rystadenergy.com/newsevents/news/press-releases/global-oil-and-gasdiscoveries-reach-four-year-high-in-2019/> accessed 1 May 2020

- 'Government Support Schemes For COVID-19' (TMF Group, 2020) <https://www.tmfgroup.com/en/news-insights/coronavirus/government-support-schemes/> accessed 1 May 2020

- Goldthau (ed) A, The Handbook Of Global Energy Policy (Wiley-Blackwell 2013)

- Grayson L, National Oil Companies (John Wiley \& Sons Ltd 1981)

- 'Guyana To Establish National Oil Company Soon - Guyana Chronicle' (Guyana Chronicle, 2018) <http:/guyanachronicle.com/2018/05/20/guyana-to-establish-national-oil-companysoon> accessed 30 April 2020

- 'Guyana: Country Review' (CountryWatch, 2019) $<$ http://www.countrywatch.com/intelligence/countryreviews?countryid=72> accessed 30 April 2020

- 'Guyana's Dodgy Poll Is All About Oil' (The Economist, 2020) $<$ https://www.economist.com/leaders/2020/03/19/guyanas-dodgy-poll-is-all-about-oil> accessed 23 March 2020

- Hantke-Domas M, 'The Public Interest Theory Of Regulation: Non-Existence Or Misinterpretation?' (2003) 15 European Journal of Law and Economics

- Hartley P, and Medlock K, 'A Model Of The Operation And Development Of A National Oil Company' (2008) 30 Energy Economics

- Heller P, 'National Oil Company Database: Global Launch' (National Resources Governance Institute, $<$ https://www.nationaloilcompanydata.org/api/publications/content/MvBx7qBCgtu0iILVzQG U2yhswUiFrmxxdwNuaT9C.pdf> accessed 25 June 2019

- Heller P, 'Doubling Down: National Oil Companies As Instruments Of Risk And Reward' (Econstor.eu, 2017) <https://www.econstor.eu/bitstream/10419/163051/1/884543331.pdf> accessed 2 January 2019 
- Ike C, and Lee H, 'Measurement Of The Efficiency And Productivity Of National Oil Companies And Its Determinants' (2014) 17 Geosystem Engineering

- Inkpen A. C, and Moffett M. H, The global oil \& gas industry: Management, strategy and finance (PennWell Books 2011)

- James O, 'Regulation Inside Government: Public Interest Justifications And Regulatory Failures' (2000) 78 Public Administration

- Jolly J, 'Anger Over World Bank's \$55M Pledge To Guyana's Fossil Fuel Industry | World Bank' (The Guardian, 2020) <https://amp.theguardian.com/business/2020/feb/27/world-bankguyana-fossil-fuel-industry-climate?_twitter_impression=true > accessed 1 March 2020

- Keeler T. E, 'Theories Of Regulation And The Deregulation Movement' (1984) 44 Public Choice

- Khan, Petroleum Resources And Development (Belhaven 1988)

- Khan A, 'Guyana Begins Receiving Royalty From Oil On April 30' (Department of Public Information, 2020) <https://dpi.gov.gy/guyana-begins-receiving-royalty-from-oil-on-april30/> accessed 1 May 2020

- Krauss C, 'With A Major Oil Discovery, Guyana Is Poised To Become A Top Producer' (The New York Times, 2017) <https://www.nytimes.com/2017/01/13/business/energyenvironment/major-oil-find-guyana-exxon-mobile-hess.html> accessed 1 May 2020

- Kurmanaev A, 'Crisis Deepens In Tiny Guyana, The World's Newest Petro State' (The New York Times, 2020) <https://www.nytimes.com/2020/03/06/world/americas/Guyanaelection.html> accessed 10 March 2020

- Kuzemko C, Lawrence A, and Watson M, 'New Directions In The International Political Economy Of Energy' (2019) 26 Review of International Political Economy

- LeVine S, 'The Surprising Next Oil Superpower' (AXIOS, 2019) $<$ https://www.axios.com/guyana-could-become-the-next-wealthy-oil-nation-b7d7c831-10ae4a40-bfe5-cb4e9c58d10f.html> accessed 6 May 2020

- $\quad$ Linde C, The State And The International Oil Market (Kluwer Academic Publishers 2000) 
- Mangal J, 'Regulatory \& Risk: Securing Guyana's Future The Opportunities And The Risks' (Guyana Petroleum Summit, 2019) <https://www.guyanapetroleumsummit.com/home> accessed 30 April 2020

- Manning A, 'COVID-19 Updates: US Federal \& State Government Relief Programs' (Linnworks, 2020) <https://blog.linnworks.com/covid-19-us-government-relief-programs> accessed 1 May 2020

- Matthews C, and Vyas K, 'World's Biggest New Oil Find Turns Guyana Upside Down' (The Wall Street Journal, 2020) <https://www.wsj.com/articles/worlds-biggest-new-oil-find-turnsguyana-upside-down-11582909332?redirect=amp\#click=https://t.co/PBMgPbuRXS> accessed 29 February 2020

- Marcel V, and Mitchell J, Oil Titans: National Oil Companies In The Middle East (Chatham House 2006)

- Maugeri L, 'Oil: The Next Revolution' [2012] The Geopolitics of Energy Project $<$ http://indianstrategicknowledgeonline.com/web/Oil-\%20The\%20Next\%20Revolution.pdf $>$ accessed 8 November 2018

- McPherson C, and World Bank Group, 'National Oil Companies Evolution, Issues, Outlook National Oil Companies Workshop Current Roles and Future Prospects' (World Bank Washington D.C. 2003)

- Mitchell J, Marcel V, and Mitchell B, 'What Next For The Oil And Gas Industry' (Chatham House, $<$ https://www.chathamhouse.org/sites/files/chathamhouse/public/Research/Energy,\%20Envir onment\%20and\%20Development/1012pr_oilgas.pdf $>$ accessed 10 February 2018

- Mihalyi D, and Bauer A, 'Challenges And Opportunities In Managing Guyana's Oil Wealth' (2020) 18 OGEL

- Mommer B, Global Oil And The Nation State (Oxford University Press 2002)

- Moorthy V, 'The Malaysian National Oil Corporation — Is It A Government Instrumentality?' (1981) 30 International and Comparative Law Quarterly

- 'National Oil Companies (NOCs)' (Extractives Hub, 2020) $<$ https://extractiveshub.org/servefile/getFile/id/4220> accessed 27 February 2020. 
- Orazgaliyev S, 'State Ownership And Nationalization In Energy Sector: The Case Of Kazakhstan's Oil Industry' [2019] Asian Development Bank Institute Working Paper No. 1042

- Ostrowski W, and Dannreuther (eds) R, Global Resources Conflict And Cooperation (Palgrave Macmillan 2013)

- 'Petroleum - Schlumberger Oilfield Glossary' (Glossary.oilfield.slb.com, 2018) $<$ http://www.glossary.oilfield.slb.com/en/Terms/p/petroleum.aspx> accessed 3 May 2019

- 'Petroleum | Energy, Products, \& Facts' (Encyclopedia Britannica, 2018) $<$ https://www.britannica.com/science/petroleum $>$ accessed 3 December 2019

- Posner R, 'Theories Of Economic Regulation' (1974) 5 Bell Journal of Economic

- Ramnarine K, 'Considerations For A Regulatory Framework To Granting E\&P Rights A Regional Perspective' (Guyana Petroleum Summit, 2019) $<$ https://www.guyanapetroleumsummit.com/page/1421919/presentations $>$ accessed 30 April 2020

- Ramson Jr. C, 'Guyana Missed Golden Opportunities To Have National Oil Company With Interest In Offshore Blocks' (Kaieteur News, 2019) $<$ https://www.kaieteurnewsonline.com/2019/04/12/guyana-missed-golden-opportunities-tohave-national-oil-company-with-interest-in-offshore-blocks-ramson-jr/> accessed 30 April 2020

- Raszewski (ed) S, The International Political Economy Of Oil And Gas (Palgrave Macmillan 2018)

- Sarraf M, and Jiwanji M, 'Beating The Resource Curse: The Case Of Botswana' (The World Bank, 2001) $<$ https://openknowledge.worldbank.org/bitstream/handle/10986/18304/multi0page.pdf?seque nce $=1>$ accessed 7 March 2019.

- Sarbu B, Ownership And Control Of Oil: Explaining Policy Choices Across Producing Countries (Routledge 2014)

- Schaik J, 'How Governments Sell Their Oil' (Resourcegovernance.org, 2012) $<$ https://resourcegovernance.org/sites/default/files/OilSales-HowGovtsSellOil.pdf $>$ accessed 20 February 2020 
- Shleifer A, 'Understanding Regulation' (2005) 11 European Financial Management

- Smith E, 'A Status Report On Economic And Political Conditions In Guyana, A World Class Hydrocarbon Discovery' (2020) 18 OGEL

- Stevens P, 'National Oil Companies And International Oil Companies In The Middle East: Under The Shadow Of Government And The Resource Nationalism Cycle' (2008) 1 The Journal of World Energy Law \& Business

- Stevens P, 'National Oil Companies: Good Or Bad' $<$ https://pdfs.semanticscholar.org/49e9/e0b16dd0bb57fbb6c996ec0f5c5cfb2babbd.pdf $>$ accessed 4 February 2018.

- Takatsuka H, Zeng D and Zhao L, 'Resource-Based Cities And The Dutch Disease' (2015) 40 Resource and Energy Economics

- Taverne B, Petroleum, Industry And Governments (2nd edn, Wolters Kluwer 2013)

- Taverne B, An Introduction To The Regulation Of The Petroleum Industry (Graham \& Trotman 1994)

- 'The National Oil Company Database: Report' (National Oil Company Database, 2019) $<$ https://www.nationaloilcompanydata.org/api/publications/content/NFInSnhdYNC4ntCohaY qok1u2jHAG4vvLXK1jwrL.pdf> accessed 25 June 2019

- Thurber M, 'Nocs And The Global Oil Market: Should We Worry' (Energy.stanford.edu, 2012) $<$ https://energy.stanford.edu/sites/g/files/sbiybj9971/f/thurber_energy_seminar_nocs_06feb20 12_final_0.pdf $>$ accessed 7 January 2020

- Tordo S, Tracy B, and Arfaa N, National Oil Companies And Value Creation (World Bank 2011)

- van der Ploeg F, 'Fossil Fuel Producers Under Threat' (2016) 32 Oxford Review of Economic Policy

- van der Ploeg F, 'Natural Resources: Curse Or Blessing?' (2011) 49 Journal of Economic Literature 
- Venables A, 'Using Natural Resources For Development: Why Has It Proven So Difficult?' (2016) 30 Journal of Economic Perspectives

- Victor D, Hults D, and Thurber (eds) M, Oil And Governance(Cambridge University Press 2014)

- Vrankel P, 'The Rationale Of National Oil Companies' (1978) 2 OPEC Review

- Waelde T, 'International Energy Investment' (1996) 17 Energy Law Journal

- Whitfield L, and Buur L, 'The Politics Of Industrial Policy: Ruling Elites And Their Alliances' (2014) 35 Third World Quarterly

- 'Who's Who In The Oil And Gas Sector In Guyana' (OilNow, 2020) $<$ https://oilnow.gy/profiles/companies/whos-who-in-the-oil-and-gas-sector-in-guyana/> accessed 30 April 2020

- Yergin D, The Prize (Simon \& Schuster 2012) 